\author{
(c) (i) (8) \\ Jurnal Terapan Manajemen dan Bisnis is licensed under \\ A Creative Commons Attribution-Non_Commercial 4.0 International License.
}

\title{
The Influence of Liquidity, Solvency, and Exchange Rate to Company Profitability and It's Implication to Stock Price at Mining Sector Company
}

\author{
Hari Gursida ${ }^{1)}$ \\ 1)Post Graduate, Pakuan University, Bogor, Indonesia \\ E-mail: hg.gursida@gmail.com
}

\begin{abstract}
This study aims to determine the effect of Liquidity, Solvency, and Exchange Rates on Stock Price, either directly or indirectly through Profitability. This research uses descriptive quantitative approach by using mining sector company listed in BEI period 20112015 as its object. Sampling method used is purposive sampling, so there are 11 companies that meet the criteria as a sample. This research proxy liquidity variable with cash ratio, solvency with debt to asset ratio, exchange rate with rupiah exchange rate to USD, profitability with return on asset. The estimation method used in this research is Structual Equation Modeling to test the research hypothesis. Based on the results of research indicate that Cash Ratio, DAR, and Exchange Rate does not directly influence Stock Price, while ROA has direct effect on Stock Price. Cash Ratio, DAR, and Exchange Rate have a significant effect on Stock Price through ROA as moderating variable.
\end{abstract}

Keywords: liquidity, solvency, exchange rate, profitability, and stock price

\section{Introduction}

Energy has a very important role for Indonesia's economic development, not only as a source of fuel and industrial raw materials but also as one of the main sources of state revenue. The energy sector, including the mining and mineral sectors, is the second largest revenue-generating sector after taxes [1]. Energy sector contribution to state revenues decrease in 2012 to 2016. In 2012 the share of energy revenues to total domestic revenues contributed 23 percent, while in 2013 it fell to 21.8 percent. In 2014, fell to 19.6 percent, while in 2015 fell to 9.8 percent. In 2016 the energy sector contributes only 6.8 percent to domestic revenues. [2]. Despite an increase in the number from 2012 to 2014, however, the percentage of contribution appears to be declining. This is due to the increase in total state revenues from 2012 to 2016. The contribution of the energy sector to total state revenues can be seen in Figure 1.

Based on Figure 1 above, seen in 2012, energy sector revenues amounted to Rp305.9 billion, or equivalent to $22.9 \%$ contribution to total state revenues amounting to Rp1338.1 trillion. Contributions in 2013 increased by Rp311.86 billion, but the percentage decreased to $21.7 \%$ of total state revenues of Rp1438.9 trillion. In 2014 there was an increase from the previous year to Rp319.69 billion, but the percentage went back down to $20.6 \%$ of total state revenues amounting to Rp1550.6 trillion. In 2015 there was a significant decline from 2014 to 
Rp146.4 billion, equivalent to $9.7 \%$ of its contribution to total state revenues of Rp1508.02 trillion. Year 2016 continues to decline to Rp122, 2 billion, or only have a contribution of 6.8 percent of total state revenues amounting to Rp1786, 23 trillion.

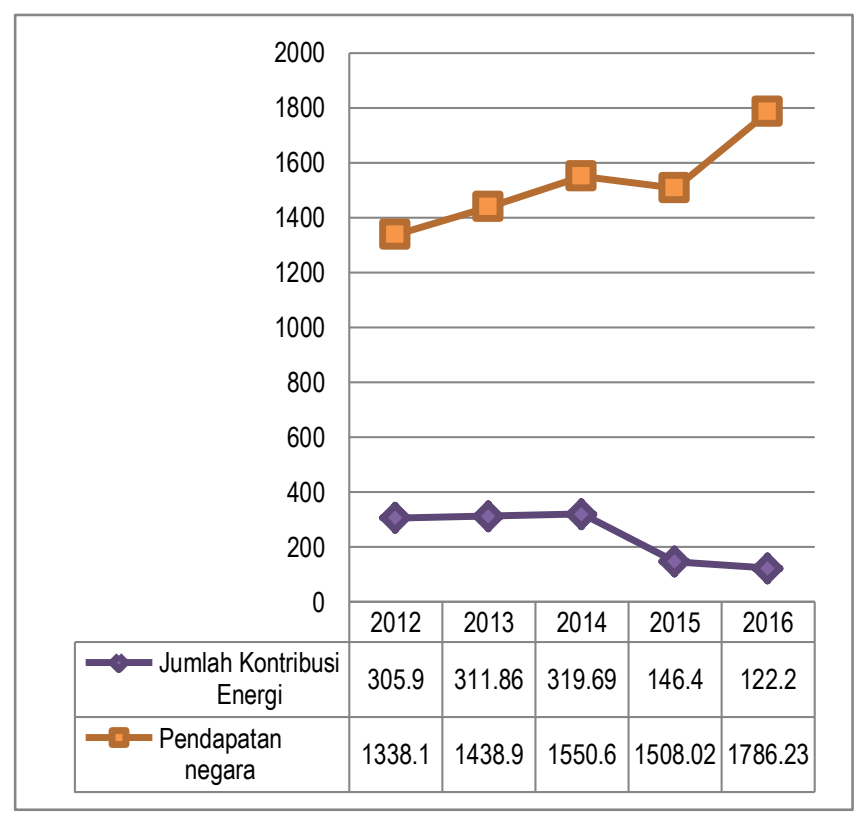

Fig.1 The contribution of the energy sector to the country's revenue, in 2012-2016

The decline in energy sector contribution is influenced by three main factors, namely the declining energy prices, the declining production factor especially for the oil commodities, and the increasing domestic consumption so that energy consumption is widely used to fulfill domestic needs. In recent years, world crude oil prices have dropped dramatically to the lowest level of US \$ 35 per barrel by the end of 2015. In 2016 the price of oil is around US $\$ 50$ per barrel [2].

The sectoral economic performance is inseparable from the performance of the industrial sector supported by companies engaged in existing business sectors. The sectoral economic performance in 2014, cumulatively indicates the electricity and gas sectors, construction, transportation and warehousing, accommodation and food beverages, information and communications, business services, education, health and other services as sectors that have GDP growth above economic growth Indonesia. The mining and quarrying sectors are the lowest growth sectors. This is because world mining commodity prices are experiencing price declines, following weak demand from China and the Minerba Act that contributed to suppressing mining growth from the internal side [3].

High growth sectors provide relatively better business sector prospects by 2016 . Based on sectoral economic performance in 2014 and 2015, transportation and communications, trade, hotels and restaurants, construction, finance, real estate and the company's services provide good prospects in 2016. Conversely, if based on low growth, the mining and quarrying sectors lack good prospects for business by 2016. Moreover, the sector is particularly vulnerable to the volatility of world commodity prices.

Low growth and lack of prospects for the mining sector could have an impact on stock price reductions. Stock prices can be considered important in a stock investment, because of the stock price investors can provide an objective measure of the value of investment in the company. The increase and decline in stock prices have an impact on both parties, both companies and investors. For the company, high stock prices will increase the 
value of the company, so many investors who will invest in the company, while for investors can increase the return that will be obtained from the shares owned. Decrease in stock prices will also reduce the value of the company in the eyes of investors, while for investors can cause losses to capital invested in the company. [4]

The mining sector listed on the Indonesia Stock Exchange has several sub-sectors, including the coal, oil and gas sub-sectors, metals and minerals, experiencing strong shocks after the 2008 global crisis, particularly the coal sub-sector. The impact of the 2008 crisis is still felt today in the mining sector which causes the decline in stock prices. The average stock price in the mining sector in 2011-2015 is presented in figure 2.

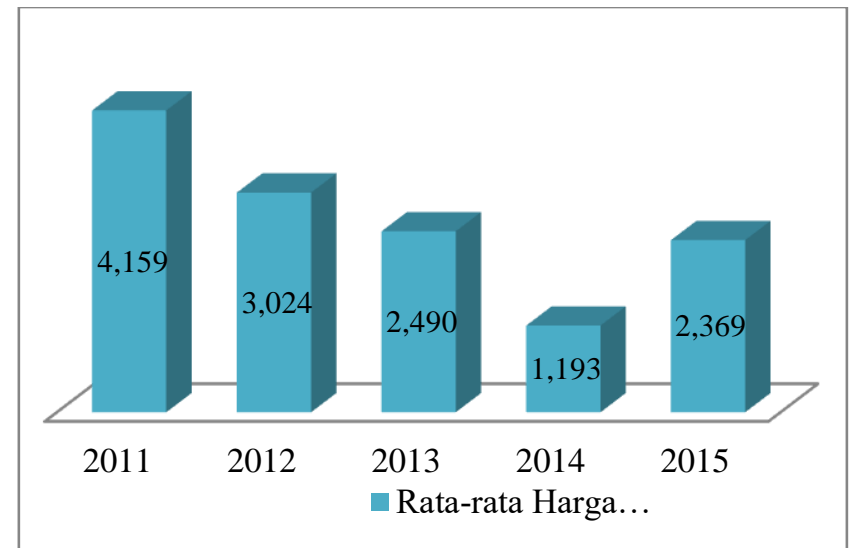

Fig. 2 Average Stock Price of Mining Sector Year 2011-2015

Based on Figure 2 above, the average stock price in 2011 amounted to $\operatorname{Rp} 4,159.00$ which decreased to $\operatorname{Rp~3,024.00~in~2012.~The~decline~in~average~stock~price~continued~to~occur~}$ in the year 2013 to $R p 2,490.00$, and back down to $R p 1,193.00$ in 2014. The average stock price of the mining sector increased to Rp 2,369.00 in 2015, although not as much as in 2013. Many factors have caused a decline in stock prices, such as economic conditions, exchange rates, corporate performance, even the political and security conditions of a country.

Factors affecting stock price fluctuations in mining companies come from internal and external factors of the company. Stock prices that occur in the stock market always fluctuate from time to time. Such stock price fluctuations will be determined by the strength of supply and demand. The number of offers greater than the number of requests, generally the stock price will decrease. However, if the amount of demand is greater than the amount of the bid on an effect, the stock price will likely increase. The amount of demand for an effect can be affected by the company's ability to generate profits, while profit generated by the firm is influenced by many factors, such as liquidity, solvency, and macroeconomic fundamentals such as exchange rates [5]. 


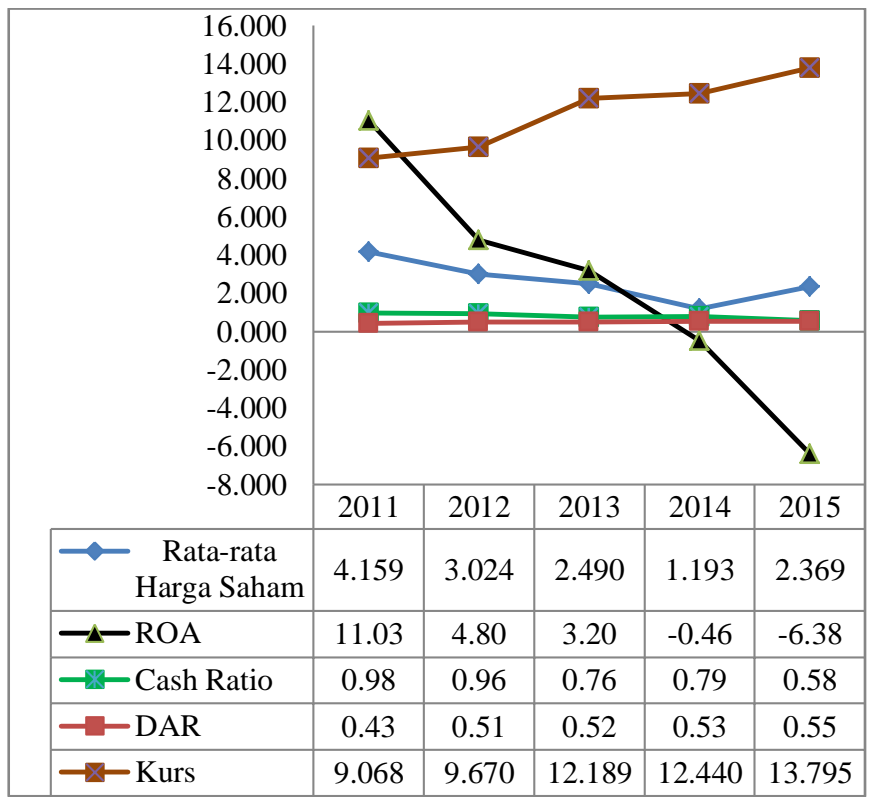

Fig. 3 Average stock price, ROA, cash ratio, DAR, and exchange rate of mining sector in 2011-2015 [11]

Figure 3 above shows the average stock price paired with ROA (profitability ratios), Cash Ratio (liquidity), Debt Ratio (solvency) in mining sector companies in 2011-2015, and Rupiah/USD. The average stock price of mining companies declined from 2011 to 2014, and moved up in 2015. The decline in stock price averages can be caused by many factors one of which is the ability of the company to produce profit or profitability. Profitability can be measured by Return on Assets (ROA). From the figure above can also be seen the decrease of ROA significantly from 2011 to 2015. The decrease in ROA can be caused by internal factors in the form of liquidity and solvency of the company (Tandelilin, 2010). The graph above shows the average liquidity of mining companies as measured by the Cash Ratio continues to decline from 2011-2015, while the average solvency measured by the Debt to Asset Ratio (DAR) continues to increase despite not very significant. In addition to internal factors, external fundamental factors one of which is the exchange rate or exchange rate can affect the level of profitability of the company. The exchange rate continues to move up which means weakened from the year 2011-2015.

Based on the background of the problem as described above, and based on the consideration of previous research on the influence of liquidity, solvency, and exchange rate on the profitability of the company and its effect on the stock price, then the purpose of this study is to analyze "The influence of liquidity, solvency, and exchange rate to profitability as well as its implications for stock price at mining sector companies listed on the stock exchange for the period 2011-2015."

Based on the formulation of the problems described above, the objectives in this study are as follows:

1. To analyze direct effect between liquidity, solvability, exchange rate, and profitability to stock price at mining sector companies listed in BEI period 2011-2015.

2. To analyze the direct effects between liquidity, solvency, and exchange rate on profitability in the mining sector companies listed in IDX period 2011-2015. 
3. To analyze the indirect effects between liquidity, solvency, and exchange rate to stock price through profitability as a moderating variable in mining sector companies listed in BEI period 2011-2015.

4. To analyze the totall effect between liquidity, solvency, and exchange rate to stock price through profitability as a moderating variable in mining sector companies listed in BEI in 2011-2015.

\section{Research Methods}

The method of analysis used is path analysis, as presented in the following figure.

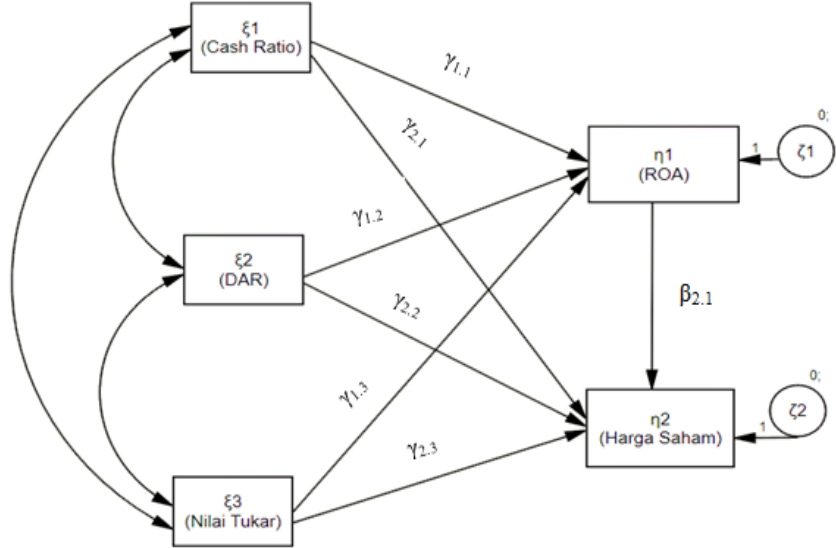

Fig.4 The constellation of research

Based on Figure 4 above shows the direct effects between liquidity, solvency, exchange rate, and profitability to stock prices, as well as direct effects between liquidity, solvency, and exchange rate on profitability. In addition to direct influence, the framework images also show indirect effects between liquidity, solvency, and exchange rates against stock prices through profitability as a moderating variable, as well as the total effects between liquidity, solvency, and exchange rate against prices shares through profitability as a moderating variable in the mining sector companies listed on the IDX period 2011-2015.

\section{Results and Discussion}

\section{A. Test Goodness of Fit}

The use of SEM techniques in a research must meet the requirements of the Goodness of Fit Test. This study uses several Goodness of Fit tests which include $\chi 2$-Chi-Square Statistic, The Root Mean Square Error of Approximation (RMSEA), CMIN/DF, Tucker Lewis Index (TLI), and Comparative Fit Index (CFI).

1) $\chi^{2}$-Chi-Square Statistic

Chi-Square Statistic $(\chi 2)$ is a statistical test to recognize the difference between population covariance matrix and sample covariance matrix. The tested model will be considered good if its chi-square value is low with probability with a cut-off value of $p>0.05$. ChiSquare value in this study is 2.849 with a probability of 0.091 which means greater $(>)$ than 0.05. Based on this, then the research model is considered good or fit. The following table shows the test results $\chi 2$-Chi-Square Statistic. 
Table 1

Test Results X²-Chi-Square Statistic

\begin{tabular}{lccccr}
\hline Model & NPAR & CMIN & DF & P & CMIN/DF \\
\hline Default model & 19 & 2.849 & 1 & .091 & 2.849 \\
Saturated model & 20 & .000 & 0 & & \\
Independence model & 10 & 85.286 & 10 & .000 & 8.529 \\
\hline
\end{tabular}

2) $\mathrm{CMIN} / \mathrm{DF}$

CMIN / DF is one of the indicators to measure the fit level of a model. CMIN / DF is ChiSquare statistics divided by its DF so-called $\chi 2$-relative. CMIN / DF or $\chi 2$-expected relative $\leq 2.0$. The CMIN / DF in this study contained in Table 24 above is 2.849 , where this value is greater than 2.0. Based on CMIN / DF this research model is considered not good.

3) The Root Mean Square Error of Approximation

RMSEA is an index that can be used to compensate Chi-Square Statistics in large samples. The RMSEA value shows the goodness-of-fit that can be expected when the model is estimated in the population. A RMSEA value smaller or equal to 0.08 is an index for theacceptability of a model. The following table shows the results of the RMSEA test. 
Table 2

Test Results $\chi^{2}$-Chi-Square Statistic

\begin{tabular}{lrrrr}
\hline Model & RMSEA & $\begin{array}{r}\text { LO } \\
90\end{array}$ & $\begin{array}{r}\text { HI } \\
90\end{array}$ & PCLOSE \\
\hline $\begin{array}{l}\text { Default } \\
\text { model }\end{array}$ & 0.136 & 0.000 & 0.333 & 0.132 \\
$\begin{array}{l}\text { Independence } \\
\text { model }\end{array}$ & 0.274 & 0.222 & 0.330 & .000 \\
\hline \hline
\end{tabular}

Based on the above table, the RMSEA value in this study is 0.136. Model results of 0.136 greater than 0.08 so that this research model is considered less well based on the RMSEA test.

4) Comparative Fit Index (CFI)

CFI is an index whose size is not influenced by the sample size because it is excellent for measuring the acceptability of a model. CFI lies in the range of values $0-1$, which is closer to 1 indicating the highest level of fit. Expected CFI of $\geq 0.95$. Based on Table 3 below, the CFI value in this study is 0.975 , where this value is greater than 0.95 so that the research model is considered good or fit. The following table shows the results of the CFI test.

Table 3

Test Results Comparative Fit Index (CFI)

\begin{tabular}{lrrrrr}
\hline Model & $\begin{array}{r}\text { NFI } \\
\text { Delta1 }\end{array}$ & $\begin{array}{r}\text { RFI } \\
\text { rho1 }\end{array}$ & $\begin{array}{r}\text { IFI } \\
\text { Delta2 }\end{array}$ & $\begin{array}{r}\text { TLI } \\
\text { rho2 }\end{array}$ & CFI \\
\hline $\begin{array}{l}\text { Default } \\
\text { model }\end{array}$ & 0.967 & 0.666 & 0.978 & 0.754 & 0.975 \\
$\begin{array}{l}\text { Saturated } \\
\text { model }\end{array}$ & 1.000 & & 1.000 & & 1.000 \\
$\begin{array}{l}\text { Independence } \\
\text { model }\end{array}$ & 0.000 & 0.000 & 0.000 & 0.000 & 0.000 \\
\hline \hline
\end{tabular}

Based on Goodness of Fit test which includes $\chi 2$-Chi-Square Statistic, The Root Mean Square Error of Approximation (RMSEA), CMIN / DF, Tucker Lewis Index (TLI), and Comparative Fit Index (CFI), yield two tests showing fit an research model that is Chi-Square Statistic and Comparative Fit Index (CFI). Based on this, then the model in this study has been considered good or fit. 


\section{Path Analysis Results}

\section{Direct Effects Cash Ratio, DAR, and Exchange Rate on Stock Price}

Path analysis is an extension of multiple linear regression analysis to determine the effect of independent variables on the dependent variable either directly or indirectly. The following table shows the results of path analysis of direct effects between Cash Ratio, DAR, Exchange Rate, and ROA Against Stock Price.

Table 4

Direct Effects Cash Ratio, Dar, Exchange Rate, Roa To Stock Price

\begin{tabular}{lrr}
\hline \hline \multicolumn{2}{c}{ Direct Effects } & Estimate \\
\hline \hline Stock Price & $\leftarrow$ CASH &,- 026 \\
Stock Price & $\leftarrow$ DAR & -0.142 \\
Stock Price & $\leftarrow$ EXR & 0.154 \\
Stock Price & $\leftarrow$ ROA & 0.608 \\
& & \\
\hline \hline
\end{tabular}

Based on the above table, it can be seen direct effects between cash ratio, DAR, exchange rate, and ROA against Stock Price which yields the following equation:

$$
\begin{gathered}
\mathrm{SP}=-0,026 \mathrm{CASH}-0,142 \mathrm{DAR}+0,154 \mathrm{EXR} \\
+0,608 \mathrm{ROA}
\end{gathered}
$$

The above equation has the meaning that will be described as follows:

1) Cash Ratio has a direct effext on Stock Price of 0.026. Cash Ratio has negative or opposite effect on Stock Price. The Stock price will decrease by 0.026 units if the Cash Ratio rises by one unit, provided that the DAR, exchange rate and ROA are zero or constant.

2) DAR has a direct effect on Stock Price of 0.142. DAR has negative or opposite effect on Stock Price. Stock Price will fall by 0.142 units if the DAR value goes up by one unit, provided that the Cash Ratio, exchange rate and ROA are zero or constant.

3) The exchange rate has a direct effect on the Stock price of 0.154 . The exchange rate has a positive or unidirectional effect on Stock Price. Stock Price will rise by 0.154 units if the exchange rate rises by one unit, provided that the Cash Ratio, DAR, and ROA are zero or constant.

4) ROA has a direct influence on Stock price of 0.608. ROA has a positive or unidirectional effect on Stock Price. Stock Price will rise by 0.608 units if ROA goes up by one unit, provided that the Cash Ratio, DAR, and exchange rate are zero or constant value.

Significance test of direct effects between Cash Ratio, DAR, Exchange Rate, and ROA Against Stock Price, will be shown in the following table. 
Table 5

Significance Test Of Cash Ratio, DAR, Exchange Rate, and ROA to Stock Price

\begin{tabular}{cccccccc}
\hline \hline & & & Estimate & S.E. & C.R. & P & Keterangan \\
\hline SP & $\leftarrow$ & CASH & $-0,027$ & 0,082 & $-0,327$ & 0,744 & Not significant \\
SP & $\leftarrow$ & DAR & $-0,386$ & 0,227 & $-1,7$ & 0,089 & Not significant \\
SP & $\leftarrow$ & EXR & 0 & 0 & 1,818 & 0,069 & Not significant \\
SP & $\leftarrow$ & ROA & 0,038 & 0,006 & 6,663 & $* * *$ & Signifikan \\
\hline \hline
\end{tabular}

Based on the above Table, describes the significance of the effect between $\xi 1, \xi 2$, and $\xi 3$, and $\eta 1$ to $\eta 2$ with the following description:

1) Cash Ratio ( $\xi 1)$ has no significant effect on Stock Price ( $\eta 2)$, because the probability value is $0,744>0,05$.

2) DAR ( $(2)$ has no significant effect on Stock Price $(\eta 2)$, because the probability value is $0.089>0.05$.

3) Exchange Rate ( $\xi 3)$ has no significant effect on Stock Price ( $\eta 2)$, because the probability value is $0.069>0.05$.

4) ROA ( $\eta 1)$ has a significant effect on Stock Price $(\eta 2)$, because the probability value 0,000 $<0.01\left(^{* * *}\right.$ means significant at alpha 0.01$)$.

\section{Direct Effects Cash Ratio, DAR, and Exchange Rate Against ROA}

Direct effects between cash ratio, DAR, and exchange rate against ROA are listed in the following table:

Table 6

Direct Effects Cash Ratio, DAR, and Exchange Rate on ROA

\begin{tabular}{lrr}
\hline \hline \multicolumn{2}{c}{ Direct Effects } & Estimate \\
\hline ROA $\leftarrow$ CASH & 0.214 \\
ROA $\leftarrow$ DAR & -0.344 \\
ROA $\leftarrow$ EXR & -0.368 \\
\hline \hline
\end{tabular}

Based on Table 6 above, it can be seen Direct Effects between Cash Ratio, DAR, Exchange Rate, and against ROA resulting in the following equation:

$$
\text { ROA= 0,214 CASH - 0,344 DAR - 0,368 EXR }
$$

The above equation has the meaning that will be described as follows: 
1) Cash Ratio has a direct effect on ROA of 0.214. Cash Ratio has a positive or direct influence on ROA. ROA will rise by 0.214 units if the Cash Ratio value rises by one unit, provided that the DAR value and exchange rate are zero or constant value.

2) DAR has a direct influence on ROA of 0.344. DAR has a negative or opposite effect on ROA. ROA will decrease by 0.344 units if the DAR value goes up by one unit, provided that the Cash Ratio and exchange rate are zero or constant.

3) The exchange rate has a direct influence on the ROA of 0.368 . The exchange rate has a negative or opposite effect on ROA. ROA will fall by 0.368 units if the exchange rate rises by one unit, provided that the value of Cash Ratio and DAR is zero or constant value.

Significance test of direct effects between Cash Ratio, DAR, and Exchange Rates Against ROA, will be shown in the following table.

Table 7

Test Significance Of Cash Ratio, DAR, and Exchange Rate On ROA

\begin{tabular}{|c|c|c|c|c|c|c|c|}
\hline & & & Estimate & S.E. & C.R. & $\mathrm{P}$ & Descrip-tion \\
\hline ROA & $\leftarrow$ & EXR & -0.002 & 0.001 & -4.308 & $* * *$ & $\begin{array}{l}\text { signi- } \\
\text { ficant }\end{array}$ \\
\hline ROA & $\leftarrow$ & CASH & 3.483 & 1.391 & 2.504 & 0.012 & $\begin{array}{l}\text { signi- } \\
\text { ficant }\end{array}$ \\
\hline ROA & $\leftarrow$ & DAR & -14.891 & 3.69 & -4.035 & $* * *$ & $\begin{array}{l}\text { signi- } \\
\text { ficant }\end{array}$ \\
\hline
\end{tabular}

Source: Processed AMOS program

Based on the above table, it shows the significance value of the effect between $\xi 1$, $\xi 2$, and $\xi 3$, against $\eta 1$ with the following description:

1) Cash Ratio ( $\xi 1)$ has significant effect on ROA ( $\eta 1)$, with probability value $0,012<0,05$.

2) DAR (६2) has significant effect on ROA $(\eta 1)$, with probability value $0,000<0,01\left(^{* * *}\right.$ means significant at alpha 0,01).

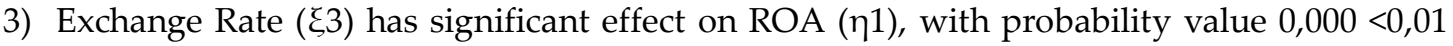
${ }^{* * *}$ means significant at alpha 0,01$)$.

\section{Indirect Effects of Cash Ratio, DAR, and Exchange Rates on Stock Price}

Indirect effects or indirect effects between Cash Ratio, DAR, and Exchange Rates Against Stock price through ROA are contained in the following table: 
Table 8

Indirect Effects Cash Ratio, DAR, and Exchange Rate on Stock Price

\begin{tabular}{lcccc}
\hline \multicolumn{5}{c}{ Standardized Indirect Effects } \\
& CASH & DAR & NT & ROA \\
\hline ROA & 0.000 & 0.000 & 0.000 & 0.000 \\
SP & 0.130 & 0.209 & -0.224 & 0.000 \\
\hline
\end{tabular}

Based on the above table, the equation of regression model from indirect effects between Cash Ratio, DAR, and exchange rate to stock price through ROA are as follows:

$$
S P=0,130 \text { CASH - 0,209 DAR - 0,224 EXR }
$$

The above equation has the meaning that will be described below:

1) Cash Ratio has an indirect effect on stock price of 0.130. Cash Ratio to stock price with ROA as moderate variable has positive or unidirectional influence. The stock price will rise by 0.130 units if the Cash Ratio rises by one unit, provided that the DAR value and exchange rate are zero or constant.

2) DAR has an indirect effect on stock price of 0.209. DAR to stock price with ROA as moderate variable has negative or opposite effect. The stock price will fall by 0.209 units if the DAR value goes up by one unit, provided that the Cash Ratio and exchange rate are zero or constant.

3) The exchange rate has an indirect effect on the stock price of 0.224 . The exchange rate against stock prices with ROA as moderate variable has a negative or opposite effect. The stock price will decrease by 0.224 units if the exchange rate rises by one unit, provided that the Cash Ratio and DAR value are zero or constant.

\section{Total Effects of Cash Ratio, DAR, and Exchange Rate on Stock Price}

The effect of total or total effects between Cash Ratio, DAR, and Exchange Rate against Stock Price with ROA as moderate variable can be seen in the following table:

Table 9

Total Effects Cash Ratio, DAR, and Exchange Rate on Stock Price

\begin{tabular}{|c|c|c|c|c|}
\hline \multicolumn{5}{|c|}{ Standardized Total Effects } \\
\hline & $\begin{array}{r}\text { CAS } \\
\mathrm{H}\end{array}$ & DAR & EXR & $\mathrm{ROA}$ \\
\hline $\mathrm{ROA}$ & 0.214 & -0.344 & -0.368 & 0.000 \\
\hline SP & 0.104 & -0.351 & -0.069 & 0.608 \\
\hline
\end{tabular}


Based on the above table, it can be seen the Total Effects between Cash Ratio, DAR, Exchange Rate, against Stock Price with ROA as a moderate variable yields the following equation:

$$
S P=0,104 \text { CASH - 0,351 DAR - 0,069 EXR + 0,608 ROA }
$$

The above equation has the meaning that will be described as follows:

1) Cash Ratio has total effects on Stock Price with ROA as moderate variable of 0.104. Cash Ratio has a positive or unidirectional effect on Stock Price. Stock Price will rise by 0.104 units if the Cash Ratio rises by one unit, provided that the DAR value and exchange rate are zero or constant.

2) DAR has total effects on Stock Price with ROA as moderate variable of 0.351. DAR has negative or opposite effect on Stock Price. The Stock price will fall by 0.351 units if the DAR value rises by one unit, provided that the Cash Ratio and exchange rate are zero or constant.

3) The exchange rate has total effects on Stock Price with ROA as moderate variable of 0.069. The exchange rate has a negative or opposite effect on the Stock price. Stock Price will fall by 0.069 units if the exchange rate rises by one unit, provided that the Cash Ratio and DAR value is zero or constant value.

4) ROA of total effects on Stock Price of 0.608. ROA has a positive or unidirectional effect on Stock Price. Stock Price will rise by 0.608 units if ROA goes up by one unit, provided that the Cash Ratio, DAR, and Exchange Rate value is zero or constant value.

\section{Coefficient of Determination}

The coefficient of determination ( $\mathrm{r} 2$ ) is intended to determine the best level of accuracy in the regression analysis, where it is indicated by the magnitude of the coefficient of determination ( $\mathrm{r} 2$ ) between 0 (zero) and 1 (one). The coefficient of determination ( $\mathrm{r} 2$ ) zero means that the exogenous variable has no effect on the endogen variable. When the coefficient of determination approaches one, it can be said that exogenous variables affect the endogenous variables, in addition the coefficient of determination ( $\mathrm{r} 2$ ) is used to determine the percentage change of endogenous variables caused by exogenous variables. The following table shows the coefficient of determination.

Table 10

Coefficient of Determination

Squared Multiple Correlations

Estimate

\begin{tabular}{ll}
\hline ROA & 0.278 \\
SP & 0.400
\end{tabular}

Based on Table 10 above, it shows that the value of determination coefficient of ROA is 0,278 or $27,8 \%$. It has the meaning that Cash Ratio, DAR, and exchange rate have contribution to ROA equal to $27,8 \%$, while the rest $72,2 \%$ influenced by factor or other variable not examined in this research. Value of coefficient of determination of stock price is 0,400 or $40,0 \%$ which mean Cash Ratio, DAR, exchange rate, and ROA have contribution 
to stock price equal to $40,0 \%$, while the rest $60,0 \%$ influenced by factor or other variable not examined in this research.

Discussion

\section{Direct Effects of Liquidity, Solvency, Exchange Rate, and Profitability on Stock Price}

The first hypothesis in this research is the direct effect of liquidity, solvency, exchange rate, and profitability to stock price at mining sector companies listed in BEI period 2011-2015. This research proxy liquidity variable with cash ratio, solvency with debt to asset Ratio, exchange rate (Rupiah/USD), Profitability with Return On Asset.

Based on the result of research, show that the value of direct effect between Cash

Ratio to stock price equal to $-0,026$ which means Cash Ratio have negative or opposite effect toward stock price. The results of this study are supported by the Arkan research [9] with the title "The Importance of Financial Ratios in Predicting Stock Price Trends: A Case Study in Emerging Markets. The research resulted Cash Ratio has negative or opposite effect toward Stock Price, negative sign means if Cash Ratio rise then stock price down. The value of significance in this study between Cash Ratio to stock price of 0.744 greater than the required level of significance of 0.05 , which means Cash Ratio no significant effect on stock prices. The value of direct effect between DAR to stock price of -0.142 which means DAR has a negative or opposite effect on stock prices. The results of this study are not in line with the Arkan research (2016). The research produces DAR has a positive effect on Stock Price, meaning that if DAR rises then the stock price will rise. Differences in the results of this study may be due to a lack of sample size, data quality or biased data, and the presence of data. The significance value of DAR to Stock Price in this study is 0.089 greater than the required level of significance of 0.05 , which means that DAR has no significant effect on stock prices.

The value of direct effect between the exchange rate to the stock price of 0.154 which means the exchange rate has a positive or unidirectional effect on stock prices. The results of this study are supported by the study [10], which states that between the variables of the Rupiah Rate (X1), Inflation (X2), and Bi Rate (X3) on Stock Prices have a positive or unidirectional effect on the Banking Sector Companies in BEI. The significance value of 0.069 is greater than the required level of significance of 0.05 , which means the exchange rate has no significant effect on the stock price. The value of direct effect between ROA to stock price of 0.608 with a significance value of 0.000 is smaller than the required level of significance of 0.05 , which means ROA has a significant effect on stock prices. The results of this study are supported by Valintino (2013), which states that ROA, CR, ROE, DER, and EPS together influence the stock price, while partially there is a significant influence between CR, ROA, and EPS on price shares in the manufacturing sector of the consumer goods industry, and there is no partial influence between ROE and DER on stock prices in manufacturing companies in the consumer goods industry.

Based on the above discussion, it can be concluded that profitability has a direct effect on stock prices, whereas there is no direct effect between liquidity, solvency, and exchange rate on stock prices in mining companies listed in BEI period 2011-2015. Hence, Hypothesis 1 or $\mathrm{H} 1$ is rejected. Partial ignorance between Cash Ratio, DAR, and exchange rate against stock prices in this study one of them is due to the presence of moderate variables, ie the profitability of companies proxied by ROA. This is supported by the theory, where profitability is the company's ability to generate profits with all capital 
working in it [6]. Profitability proxied by Return On Assets (ROA) according to Cashmere (2016) is the ratio that shows the return (return) on the amount of assets used in the company. In addition, ROA provides a better measure of the company's profitability because it shows the effectiveness of management in using assets to earn revenue. Based on the description, it can be concluded that this ROA is used to measure the comparison between net income after deducting interest and tax expense (Earning After Taxes) resulting from the principal activities of the company with total assets owned by the company to perform the activities of the company as a whole expressed in percentage. Interest expenses are closely related to the level of debt held by the company either longterm or short-term debt, the greater the company's debt the burden of the interest will increase, it can affect the profitability of the company. The total assets including the company's cash is a divisor in the ROA formula, the higher the total asset value can decrease the ROA level with the assumption that the increase in net profit is not as big as the total assets increase. The exchange rate is also one of the external factors that can affect the profitability of the company. This is because the higher the rupiah exchange rate against the USD, the lower purchasing power either the purchasing power of the community will be a product produced by the company or the purchasing power of the company against imported raw materials, in other words the high price of raw materials and baiya operational companies can lower the level of profitability company.

\section{The Influence of Liquidity, Solvency, and Exchange Rate to Profitability}

The second hypothesis in this study is that there is the influence of liquidity, solvency, and exchange rate to profitability at mining sector companies listed in BEI period 2011-2015. This research proxy liquidity variable with cash ratio, solvency with debt to asset ratio, exchange rate with rupiah/usd, profitability with return on asset.

Based on the results of the study, showed that the value of influence between cash ratio to ROA of 0.214 with a significance value of 0.012 is smaller than the required level of significance of 0.05 , which means cash ratio has a positive and significant effect on ROA. The value of influence between DAR to ROA of -0.344 with a significance value of 0.000 is smaller than the required level of significance of 0.05 , which means that DAR has a negative and significant impact on ROA. The results of this study is supported by research that states that there is a positive and significant influence partially between cash ratio, activity (TATO) to profitability (ROA), while solvency (DAR) has a negative and partially significant effect on profitability in automotive company Listed on Indonesia Stock Exchange period 2012-2014 [7]. The value of influence between exchange rate to ROA in this research is equal to -0.368 with a significance value of 0.000 smaller than the required level of significance of 0.05 , which means the exchange rate has a negative and significant effect on stock prices. The results of this study are also supported by research which states that simultaneously, exchange rate and fluctuation of IHSG have significant effect on Return on Assets. Partially, only exchange rate has a significant effect on Return on Assets, while JCI fluctuations have no significant effect on Return on Assets [5].

There are internal and external factors that can affect a company's profitability. Internal factors include the level to liquid an enterprise or liquidity, as well as how the company is able to regulate its debt levels compared with assets owned by the company as a guarantor of its debt, if the company is not able to pay off its debt. Any corporate debt is closely related to the cost or interest expense attached to the debt that can affect the rate of 
profit of the company. External factors that can affect the company one of them is the exchange rate. The exchange rate can affect the company's operating costs.

\section{Indirect Effect of Liquidity, Solvency, Exchange Rate Against Stock Price with Profitability as Moderating Variables}

The third hypothesis in this research is the indirect of liquidity, solvency, and exchange rate on Stock Price with profitability as a moderating variable in mining sector companies listed in IDX period 2011-2015. This research proxy liquidity variable with cash ratio, solvency with debt to asset ratio, exchange rate with Rupiah/USD, profitability with return on asset.

Based on the result of research, show that the value of indirect effect between Cash Ratio to stock price through ROA is 0,130 . The value of indirect effect between DAR to stock price through ROA is -0.209 , while indirect effect between exchange rate to stock price through ROA is equal to -0.224 . The value of ROA significance to stock price of 0.000 is smaller than the required level of significance of 0.05 , which means ROA has a significant effect on stock prices. Cash Ratio, DAR, and exchange rate have significant effect on ROA with significant value less than 0,05. The above, indicating that profitability variables proxied by ROA in this study can be a moderating variable, which means that the third hypothesis can be accepted. This result is supported by research that states that liquidity, solvency, and fundamentals of markro economy have a significant effect on stock prices through profitability moderation variables [12]

\section{The Total Effect between Liquidity, Solvency, Exchange Rate, and Profitability on} Stock Price with Profitability as Moderating Variables

Fourth hypothesis in this research is: there is total effect between liquidity, solvability, and exchange rate to stock price through profitability as moderator variable at mining sector company listed in BEI period 2011-2015.

The results showed that Cash Ratio has total effects on Stock Price with ROA as moderate variable of 0.104 . Cash Ratio has a positive or unidirectional effect on Stock Price. Stock Price will rise by 0.104 units if the Cash Ratio rises by one unit, provided that the DAR value and exchange rate are zero or constant. DAR has total effects on Stock Price with ROA as moderate variable of 0.351. DAR has negative or opposite effect on Stock Price. The exchange rate has total effects on Stock Price with ROA as moderate variable of 0.069. The exchange rate has a negative or opposite effect on the Stock price.

The value of coefficient of determination of ROA is 0,278 or $27,8 \%$. It has the meaning that Cash Ratio, DAR, and exchange rate have contribution to ROA equal to $27,8 \%$, while the rest $72,2 \%$ influenced by factor or other variable not examined in this research. Value of coefficient of determination of stock price is 0,400 or $40,0 \%$ which mean Cash Ratio, DAR, exchange rate, and ROA have contribution to stock price equal to $40,0 \%$, while the rest $60,0 \%$ influenced by factor or other variable not examined in this research.

\section{Conclusions}

1. Direct Effects between Cash Ratio, DAR, Exchange Rate, and ROA on Stock Price yields equation $\mathrm{SP}=-0,026 \mathrm{CASH}-0,142 \mathrm{DAR}+0,154 \mathrm{EXR}+0,608 \mathrm{ROA}+\varsigma 1$. This means that 
Cash Ratio has a direct influence on Stock Price of 0.026. Cash Ratio has negative or opposite effect on Stock Price. DAR has a direct influence on Stock Price of 0.142. DAR has negative or opposite effect on Stock Price. The exchange rate has a direct influence on the Stock price of 0.154 . The exchange rate has a positive or unidirectional effect on Stock Price. ROA has a direct influence on Stock price of 0.608. ROA has a positive or unidirectional effect on Stock Price. Cash Ratio ( $(1)$ has no significant effect on Stock Price $(\eta 2)$, since the probability value is $0.744>0.05$. DAR $(\xi 2)$ has no significant effect on Stock Price $(\eta 2)$, since the probability value is $0.089>0.05$. Exchange Rate $(\xi 3)$ has no significant effect on Stock Price $(\eta 2)$, because the probability value is $0.069>0.05$. ROA ( $\eta 1$ ) has a significant effect on Stock Price $(\eta 2)$, because the probability value is $0.000<0.01$. This means that Hypothesis 1 is rejected, meaning Liquidity, Solvency, and exchange rate have no effect on stock price.

2. Direct Effects between Cash Ratio, DAR, Exchange Rate, and ROA which yields equation $\mathrm{ROA}=0,214 \mathrm{CASH}-0,344$ DAR - 0,368 EXR + $\varsigma 2$ Cash Ratio have direct influence to ROA equal to 0,214 . Cash Ratio has a positive or direct influence on ROA. DAR has a direct influence on ROA of 0.344 . DAR has a negative or opposite effect on ROA. The exchange rate has a direct effect on the ROA of 0.368 . The exchange rate has a negative or opposite effect on ROA. Cash Ratio ( $\xi 1)$ has significant effect on ROA $(\eta 1)$, with probability value $0,012<0,05$. DAR ( $(2)$ has significant effect on ROA $(\eta 1)$, with probability value 0,000 $<0,01$. Exchange Rate ( $\xi 3)$ has significant effect on ROA ( $\eta 1)$, with probability value 0,000 $<0,01$. This means that Hypothesis 2 is accepted, meaning Liquidity, Solvency, and exchange rate have an effect on profitability. The value of coefficient of determination of ROA is 0,278 or $27,8 \%$. It has the meaning that Cash Ratio, DAR, and exchange rate have contribution to ROA equal to $27,8 \%$, while the rest $72,2 \%$ influenced by factor or other variable not examined in this research.

3. The equation of regression model from indirect effects between Cash Ratio, DAR, and exchange rate to stock price through ROA is SP =0,130 CASH - 0,209 DAR - 0,224 EXR + §3. Cash Ratio has an indirect effect on the stock price of 0.130. Cash Ratio to stock price with ROA as moderate variable has positive or unidirectional influence. DAR has an indirect effect on stock price of 0.209. DAR to stock price with ROA as moderate variable has negative or opposite effect. The exchange rate has an indirect effect on the stock price of 0.224 . The exchange rate against stock prices with ROA as moderate variable has a negative or opposite effect. ROA ( $\eta 1)$ has a significant effect on Stock Price $(\eta 2)$, because the probability value is $0.000<0.01$. It concludes that Hypothesis 3 is accepted, meaning profitability can be a moderating variable between liquidity, solvency, and exchange rate against stock price. Value of coefficient of determination of stock price is 0,400 or $40,0 \%$ which mean Cash Ratio, DAR, exchange rate through ROA have contribution to stock price equal to $40,0 \%$, while the rest $60,0 \%$ influenced by factor or other variable not examined in this research.

4. Total Effects between Cash Ratio, DAR, Exchange Rate, to Stock Price with ROA as moderate variable yields equation $\mathrm{SP}=0,104 \mathrm{CASH}-0,351 \mathrm{DAR}-0,069 \mathrm{EXR}+0,608 \mathrm{ROA}+$ $\varsigma 4$.Cash Ratio has total effect to Stock Price with ROA as moderate variable of 0.104 . Cash Ratio has a positive or unidirectional effect on Stock Price. DAR has total effects on Stock Price with ROA as moderate variable of 0.351. DAR has negative or opposite effect on Stock Price. The exchange rate has total effects on Stock Price with ROA as moderate variable of 0.069 . The exchange rate has a negative or opposite effect on the Stock price. 


\section{Acknowledgment}

Acknowledgments are submitted to the Indonesia Stock Exchange (BEI) on data provided and used in this study ( $\underline{w w w . i d x . c o . i d})$.

\section{References}

Arkan, T.. 2016. The Importance of Financial Ratiosin Predicting Stock Price Trends:A Case Study in Emerging Markets. Finanse. Rynki Finansowe, Ubezpieczenia nr 1/2016 (79). Bursa Efek Indonesia (BEI). 2016. www.idx.co.id (diakses 03 April 2017).

Darmadji, F., 2011. Pasar Modal di Indonesia. Salemba Empat:Jakarta.

Fahmi, I. 2012. Analisis Kinerja Keuangan, Panduan Bagi Akademisi, Manajer, dan Investor Untuk Menilai dan Menganalisis Bisnis dari Aspek Keuangan. Bandung: Alfabeta.

Financial Market Outlook, 2016.

Harahap, S.S.. 2010. Analisis Kritis Atas Laporan Keuangan. Jakarta: Rajawali Persada.

Munib, M. F.. 2016. Pengaruh Kurs Rupiah, Inflasi, dan BI Rate Terhadap Harga Saham Perusahaan Sektor Perbankan di BEI. eJournal Administrasi Bisnis, Universitas Mulawarman.

Tandelilin, E.. 2010. Analisis Investasi dan Manajemen Portofolio

Sutrisno. 2014. Manajemen Keuangan. Teori, Konsep dan Aplikasi. Yogyakarta: Ekonosia.

Wira, D.. 2016. Analisis Fundamental Saham, edisi kedua, Exceed:Jakarta.

www.esdm.go.id

www.lipi.go.id 